\title{
PATTERNS OF WEANING AMONG ANCESTRAL HURON-WENDAT COMMUNITIES, DETERMINED FROM NITROGEN ISOTOPES
}

\author{
Susan Pfeiffer, Judith C. Sealy, Ronald F. Williamson, Crystal Forrest, and Louis Lesage
}

\begin{abstract}
Archaeological evidence of the ancestral Huron-Wendat Nation of Southern Ontario, Canada, shows a population increase from the thirteenth through sixteenth centuries, suggesting high fertility. Birth timing and infant survival are influenced by mothers' decisions about weaning. This study explores trophic enrichment of $\delta^{15} \mathrm{~N}$ in horizontal dentine slices from 35 deciduous molars $\left(\mathrm{n}=33 d m_{1}, \mathrm{n}=2 d m_{2}\right)$ and 39 permanent first molars $\left(M_{1}\right)$ representing five Huron-Wendat ossuaries, dating from the fourteenth through seventeenth centuries. Weaning was normally incomplete at the end of dm formation, at an age of about 2.5 years. Post-weaning dentine values appear by the end of crown formation of $M_{1}$. The weaning process began between 8 and 18 months and was complete in all cases by 3.5 years. Timing of the weaning process does not support the idea that Huron-Wendat population increase was associated with early weaning of infants. Communities from the sixteenth century and thereafter show earlier completion of weaning. Reasons for earlier cessation of breastfeeding may be found in the social and biological disruptions of the era of European contact. Values from permanent teeth of mandibles with sex attributed suggest a more homogeneous, possibly venison-oriented, post-weaning diet among males.
\end{abstract}

Les évidences archéologiques des ancêtres de la Nation huronne-wendat dans le sud de l'Ontario, Canada, présentent une augmentation de population entre les treizième et seizième siècles, suggérant ainsi un haut degré de fertilité. Le moment de la naissance et la survie infantile sont influencés la date de sevrage, laquelle est décidée par la mère. Cette étude explore l'enrichissement trophique de $\delta^{15} \mathrm{~N}$ dans des tranches horizontales de dentine de 35 molaires $\left(N=33 \mathrm{dm} \mathrm{m}_{1}, N=2 \mathrm{dm} \mathrm{m}_{2}\right)$ et de 39 prémolaires permanentes $\left(M_{1}\right)$ provenant de cinq ossuaires hurons-wendat identifiés entre le quatorzième et le dix-septième siècle. Le sevrage était normalement incomplet à la fin de la formation de dm, soit à un âge d'environ 2,5 ans. Les valeurs de dentine post-sevrage apparaissaient vers la fin de la formation de la couronne de $M_{1}$. Le processus de sevrage commençait entre huit et 18 mois et était complet dans tous les cas à 3,5 ans. Le début du processus de sevrage ne supporte pas l'idée que l'augmentation de la population huronne-wendat était associée à un sevrage précoce des enfants. Les communautés du seizième siècle et ceux suivants, présentent un sevrage complété à un âge plus jeune. Les raisons expliquant l'arrêt d'un nourrissage par le sein plus hâtif peuvent être expliquées par les perturbations sociales et biologiques de l'époque du contact avec les européens. Les valeurs des dents permanentes provenant de mandibules sont le sexe est connu suggèrent une diète post-sevrage plus homogène chez les hommes, probablement influencée par la venaison.

$\mathrm{T}$ The term "weaning" describes the transition from the first introduction of foods supplementary to breast milk to the establishment of a diet that does not include breast milk (Sellen 2009). The timing of each stage within this transition can affect the health of both the child and the mother. Duration of breastfeeding varies within and among human populations from about four months to about six years (Sellen 2001). Decisions about when

\footnotetext{
Susan Pfeiffer - Department of Anthropology, University of Toronto, 19 Russell Street, Toronto, Canada M5S 2S2 (susan.pfeiffer@utoronto.ca, corresponding author)

Judith C. Sealy $\square$ Department of Archaeology, University of Cape Town, Private Bag X3, Rondebosch, South Africa 7701 (judith.sealy@uct.ac.za)

Ronald F. Williamson — Archaeological Services Inc., 528 Bathurst Street, Toronto, Canada, M5S 2P9

(rwilliamson@asiheritage.ca)

Crystal Forrest - Archaeology Programs Unit, Ministry of Tourism, Culture and Sport, 401 Bay Street, Suite 1700, Toronto, Canada M5J 2 Z3 (crystal.forrest@ontario.ca)

Louis Lesage Nation Huronne-Wendat, Bureau du Nionwentsïo, 255 Place Michel-Laveau, Wendake, Canada, G0A 4V0 (louis.lesage@cnhw.qc.ca)

American Antiquity 82(2), 2017, pp. 244-261

Copyright (C 2017 by the Society for American Archaeology. This is an Open Access article, distributed under the terms of the Creative Commons Attribution licence (http://creativecommons.org/licenses/by/4.0/), which permits unrestricted re-use, distribution, and reproduction in any medium, provided the original work is properly cited.
}

doi:10.1017/aaq.2016.36 
and how to cease breastfeeding are linked to social practices and local food resources. These decisions, in turn, can influence birth spacing, and are therefore linked to fertility. While the duration of lactational amenorrhea is determined by many factors (Snodgrass 2012), exclusive and frequent suckling interrupts the ovulatory cycle (McNeilly 1994), thereby influencing the spacing of pregnancies. In this and other ways, patterns of weaning inform our understanding of human behavior in diverse environmental contexts (Humphrey 2010; McDade 2001; Wells and Stock 2007).

The research described here explores this topic through new archaeologically derived information about a group of horticulturists whose numbers were growing prior to European intrusion, and about whom there is also ethnographic and historic information. Through the patterns of infant and childhood nutrition, we can generate information about the dynamics of growth in population numbers as well as information about the care of children within that society.

Past agricultural groups may have weaned their children at a younger age than foragers did, and this may have fueled global population expansion. In fact, Bocquet-Appel (2011) argues that the transition to agriculture allowed global human population to increase 12-fold during the Holocene, from six million hunter-fisherforagers to over seven billion people today. Farming generally supports increased dietary carbohydrate intake and a positive return on postpartum energy balance, leading to reduced birth spacing and population growth (Bocquet-Appel 2011). It is difficult to test this hypothesis, since quantitative information about infant feeding practices is sparse, extant forager groups often live in marginal circumstances, and modern commercial influences on mothers' decisions can be pervasive. Information about the infant feeding practices of past groups can be used to better understand possible patterned differences in weaning practices through space and time. The study of weaning practices can also inform us about past people's lives, by revealing crucial decisions that were made by caregivers in the past. Successful care and nurturing of infants forms the basis of any group's survival, yet information about mothers' decisions is often difficult to document.

This is the case for the Huron-Wendat of the Lower Great Lakes. While the Wendat homeland at the time of European contact was "Wendake," situated between Lake Simcoe and Georgian Bay, their immediate ancestors had occupied the north central shore of Lake Ontario. After about A.D. 1615, their political, economic, and belief systems were observed and documented by the explorer Samuel de Champlain (Biggar 1922-1936) and by missionaries such as Recollet Father Gabriel Sagard and the Jesuits (Thwaites 1896-1901; Wrong 1939). Information about childbirth, infant care, and childhood is very sparse in these records. Birth spacing appears to have been actively managed, with the use of behavioral measures to limit pregnancies. The Jesuits recorded that parents abstained from sexual intercourse during the two to three years that a child was nursed (Thwaites 1896-1901:8:127).

Sagard reported that childbirth was unaccompanied by ritual, with an expectation that women would go through labour and delivery on their own, then return to normal activities as quickly as possible after the birth (Wrong 1939:130). Cradleboards were typically used for infants, which ensured that their mothers could return to field work quickly while still being nearby for breastfeeding and care (Biggar 1922:141; Wrong 1939:129). The lack of initial fanfare for the birth does not diminish the importance of births to the community, as subsequent ceremonies performed shortly after birth served to celebrate the infant's arrival. One such ceremony involved the piercing of the infant's ears and subsequent adornment of the ears (Wrong 1939:127). Naming ceremonies for infants were considered with gravity, as infants often carried the names of family members who had died. In these instances, the infants were said to continue to embody the characteristics of their dead relatives (Thwaites 1896-1901:10:223).

While primarily breastfed, children were also given meat that the mother had chewed well (Tooker 1964:123). In the event of the death of the mother, fathers were reported to have fed children by filling their mouths with water in which maize had been boiled and placing the child's mouth against his own, thereby making 
the child take the liquid (Wrong 1939:128). Adults saw children as beneficial, as they allowed for the growth of the community and provided care for their aging parents (Wrong 1939:127). Children were encouraged to practice the skills that they would need as adults, such as shooting with a bow and arrow (boys) or pounding corn (girls) (Wrong 1939:133).

Archaeological evidence suggests that the Huron-Wendat population increased in numbers after A.D. 900, largely as a consequence of the adoption of maize agriculture (Williamson 2014). A population of over 30,000 (of HuronWendat and neighboring Tionontaté) by the early seventeenth century is thought to have been the result of "relatively low juvenile mortality and high fertility" (Warrick 2008:244) during the preceding centuries. This increase in numbers also suggests that, on a social level, Huron-Wendat parents showed significant parental investment and care. The qualitative and quantitative aspects of available food may have been components of infant feeding management.

\section{Study Context}

The research presented here is made possible by an innovative agreement between the University of Toronto and the Huron-Wendat Nation of Wendake, Quebéc. Prior to the repatriation and reburial of their ancestral remains, the HuronWendat authorized the retention of selected teeth, so that the descendants could continue to learn more about their ancestors (Pfeiffer and Lesage 2014). This work contributes to a growing compendium, providing new knowledge from the study of human teeth retained from ancestral Huron-Wendat archaeological contexts (Pfeiffer et al. 2014, 2016; van der Merwe et al. 2003). The sites represented in this study were ossuaries: secondary comingled burials that are associated with the Feast of the Dead, an important component of Huron-Wendat spiritual life (Heidenreich 1971:148-151; Tooker 1964:134-140; Trigger 1969:106-112, 1976:85-90; Williamson and Pfeiffer 2003). Descendants interred the bodies collectively in large pits constructed prior to the relocation of villages. Studies of the sites and the human remains disinterred from them confirm ethnographic observations that almost all community members were included and that the remains appear to have been purposefully comingled (Merrett 2003; Pfeiffer 1980; Pfeiffer and Fairgrieve 1994; Williamson and Steiss 2003). One demographic category normally missing from ossuaries is that of newborns. Their remains occur within or very near occupation sites, often in contexts that suggest solicitous care directed toward their burial. Studies of individual juvenile skeletons suggest that growth lagged prior to their deaths. When combined with evidence from burial modes, researchers have concluded that communities directed care toward children who had chronic ill health (Forrest 2010; Kapches 1976; Saunders and Melbye 1990).

Carbon and nitrogen isotope ratios from the retained teeth and from some fragments of adhering bone have provided a picture of HuronWendat adult diet. Consistent with other lines of archaeological evidence, isotope values indicate that reliance on maize as a primary source of food energy was established by the early fourteenth century (Pfeiffer et al. 2016; van der Merwe et al. 2003). Beans (Phaseolus vulgaris) and the Cucurbitaceae were also important plants grown by the Wendat (Hart and Lovis 2013:196); these are $\mathrm{C}_{3}$ plants. Dietary sources of animal protein were varied. There was particular reliance on diverse types of fish as well as white-tailed deer (Odocoileus virginianus). Comparison of values from teeth and bone from the same persons indicates that juveniles (mid-childhood) consumed more maize and less animal protein than adults (Pfeiffer et al. 2016). The research presented here builds on previous studies, expanding the number of permanent teeth and adding samples of deciduous teeth to explore the diets of ancestral Huron-Wendat infants and children.

\section{Tooth Development and Child Growth}

Tooth formation is a relatively predictable aspect of child growth. Enamel and pre-dentine cells begin formation synchronously, from the dentine-enamel junction (DEJ); the tooth forms from cusp tip to root apex (Hillson 2014:50). The isotopic ratios of interest are incorporated into the forming tissue, which subsequently mineralizes. Although all aspects of the mineralization process are not understood (Nanci 2012), mineralization appears to follow approximately two 
weeks after initial matrix formation (Burt and Garvie-Lok 2013).

Like radiographic studies of living children, studies of archaeologically derived dental tissues focus on the mineralized tissues. To this end, standards of dental development form the reference point. The newest such chart, based on the largest, most carefully chosen reference sample, is the London Atlas (AlQahtani et al. 2010). Hillson (2014:54) notes the improvements introduced by the London Atlas, but adds the general caution that, while "the average age at attainment of dental development stages . . . varies considerably less between populations than, say, equivalent skeletal development stages, individuals within those populations can depart in both timing and sequence from the average." Our study focuses on age of attainment of dental developmental stages, as characterized by the London Atlas.

The first deciduous mandibular molar $\left(\mathrm{dm}_{1}\right)$ begins dentine formation prior to birth (Hillson 1996:124). Mineralization is clearly apparent by 4.5 months after birth, with the crown complete by 7.5 months. By the age of 18 months, the root is half-formed, and root formation is complete by 2 to 2.5 years. Development of the $\mathrm{dm}_{2}$ is slightly behind that of the $\mathrm{dm}_{1}$. At 18 months of age, when $\mathrm{dm}_{1}$ root formation is half completed, $\mathrm{dm}_{2}$ root formation is beginning. Root formation of $\mathrm{dm}_{2}$ is complete by 3.5 years (AlQahtani et al. 2014).

Unless an infant was fed alternate foods from early infancy, the postnatal dentine from beneath the deciduous crown will reflect the isotopic enrichment associated with the consumption of mother's milk (Fogel et al. 1989; Fuller et al. 2006). Deciduous teeth come from the remains of infants and young children who did not survive to adulthood. Among Iroquoians, children who did not reach adulthood experienced stunted skeletal growth (Forrest 2010). Possibly, mothers suckled children in faltering health more, or longer, than infants and children in good health. The study of permanent teeth in addition to deciduous teeth is thus a helpful corollary, since their isotope values document the diets of children who survived at least to adolescence, and in most cases to adulthood.

The dentine of the first permanent mandibular molar is radiographically visible at the point at which the crown is one-half complete. This occurs between ages 1.5 and 2.5 years (AlQahtani et al. 2010). By 2.5 years, the crown is three-quarters complete, so dentine from beneath the enamel provides an indication of diet at that age. Root formation proceeds from 3 to 10 years (Hillson 1996:123). Because the permanent $\mathbf{M}_{1}$ begins dentine mineralization at about the same time as the $\mathrm{dm}_{1}$ completes its root formation (or slightly prior), the information provided by these two teeth represents a cross-sectional study of the continuum of development through infancy and early childhood.

\section{Stable Isotopes Applied to Infant and Child Feeding Patterns}

Researchers have explored $\delta^{15} \mathrm{~N}$ (see Methods section for definition) as a means of tracking the weaning process for several decades (Dupras 2010; Fogel et al. 1989; Humphrey 2014; Katzenberg et al. 1996; Reynard and Tuross 2015; Schurr and Powell 2005; Tsutaya and Yoneda 2015). The premise is that suckling infants are, in effect, consuming maternal body tissue and are thus a trophic level higher than adults in their community; their body tissues should therefore record elevated $\delta^{15} \mathrm{~N}$. As infants gradually incorporate other types of foods into their diets, $\delta^{15} \mathrm{~N}$ is expected to decline until it matches adult values. The degree of elevation is not well understood. From the available data (summarized in Reynard and Tuross 2015), it seems that milk is probably 2 to $3 \%$ more positive than the mother's diet. If the diet-totissue offset is the same in infants and adults, then (assuming an isotopically constant diet) the infant's bone or dentine collagen should be 2 to 3\%o more enriched than the mother's (Fogel et al. 1989; Fuller, Fuller, et al. 2006). Despite the many unknowns, studies report differences of approximately this magnitude between adults and young children (Clayton et al. 2006; Fuller, Molleson, et al. 2006; Katzenberg and Pfeiffer 1995). While this effect also applies to $\delta^{13} \mathrm{C}$ values, breastfed infants have $\delta^{13} \mathrm{C}$ values that are enriched by only about $1 \%$ over adult female values (Richards et al. 2006). Discernment of such a small enrichment is difficult. It should be noted that nitrogen in consumer tissue 
derives primarily from dietary protein, although small amounts may be incorporated from other sources, e.g., dietary urea, via gut microflora (Reynard and Tuross 2015). Therefore, $\delta^{15} \mathrm{~N}$ tracks the protein component of the diet, rather than the whole diet.

Studies based on bone collagen have generated information about the timing and pace of weaning among various past communities (Clayton et al. 2006; Katzenberg and Pfeiffer 1995; Schuur and Powell 2005; Wright and Schwarcz 1999). Challenges associated with that research include the frequent lack of precision in estimates of age at death, the frequently small number of infant and child skeletons available for study, and uncertainty in the isotopic trophic offsets (Reynard and Tuross 2015).

Serial assessment of dental tissue provides a way to reconstruct infant and child diet from the teeth of persons who did not die until long after tooth formation was complete (Beaumont et al. 2012; Burt 2015; Burt and Garvie-Lok 2013; Dupras and Tocheri 2007; Eerkens et al. 2011; Fuller et al. 2003). By focusing on permanent molars, this approach supports the exploration of sex differences (Eerkens and Bartelink 2013), since mature skeletal material can be differentiated in ways that infant and juvenile skeletal material cannot. This methodological approach also has been used to explore the characteristics of post-weaning diets during childhood (Eerkens et al. 2016; Greenwald et al. 2016). Horizontally positioned slices do not neatly match the archlike pattern of dentine growth, but contiguous slices do provide a rolling average of isotopic values within the sequentially developing dentine.

\section{Materials}

\section{Five Ossuaries}

The five communities in this study all practiced secondary, ossuary burial. While other Iroquoian speakers of the broader region also practiced communal burial, Ancestral HuronWendat ossuaries are deep pits (Williamson and Steiss 2003), in which the bones are comingled in a manner consistent with observers' accounts of purposeful mixing (Pfeiffer 1980). This mixing, combined with pressure from subsequent above- ground activities and top-down excavation methods, led to a great deal of bone breakage, which in turn limited reconstruction of individual broken bones and normally precluded the identification of individual skeletons. Ossuaries constructed prior to the arrival of Europeans tend to contain very few artifacts, making it difficult to associate them with the villages whose members built them (Figure 1, Table 1). The three oldest ossuaries in this study (Fairty, Uxbridge, and Kleinburg) were situated just north of Toronto while the seventeenth-century sites were further north in Simcoe County, the location of the historic homeland of the Huron-Wendat, now referred to as Old Wendake. The consolidation of the Huron-Wendat confederacy occurred there, after the movement of communities from the north shore of Lake Ontario and the Trent Valley (Birch and Williamson 2013; Williamson 2014:29-42).

Excavated in 1956, the Fairty ossuary included the skeletal remains of at least 512 persons (Anderson 1963; Gruspier 1999; Pfeiffer and Fairgrieve 1994). Unfortunately, details regarding the exact location and excavation of the site were lost. Lacking diagnostic artifacts, the site's age comes from radiocarbon dating of a human tooth (Beta-397304, 690 \pm 30 B.P.; $\delta^{13} \mathrm{C}=-11.4 \%$ ), which provided two sigma calibrated ages ranges of A.D. 1265-1312 $(p=0.69)$ and 1358-1388 $(p=0.26)$. One of the ossuary's associated villages may be the fourteenth-century Robb site, a roughly 2 ha unpalisaded village consisting of nine widely spaced longhouses and an extensive midden on a slope above Milliken Creek, a tributary of the Rouge River (Williamson 2014:18-19). Given the number of people documented in the ossuary, more than one village may have contributed to its formation.

Excavated from 1975 to 1977, the Uxbridge ossuary included the remains of at least 457 persons. Pfeiffer and Fairgrieve (1994) summarize studies of the skeletal collection, but no publication describes the excavation. Lacking diagnostic artifacts, the site's age comes from radiocarbon dating of charcoal found $182 \mathrm{~cm}$ below the ossuary's surface (I-9865, $460 \pm 80$ B.P.) and an AMS date on a human tooth (Beta 403922, $460 \pm 30 \mathrm{BP} ; \delta^{13} \mathrm{C}=-10.0 \%$ ). The first date calibrates at two sigma to A.D. to 1311-1359 
Table 1. Archaeological Sites Included in Study.

\begin{tabular}{|c|c|c|c|c|c|c|}
\hline \multirow[b]{3}{*}{ Site name } & \multirow[b]{3}{*}{ Context/Century } & \multirow[b]{3}{*}{ Sources } & \multicolumn{4}{|c|}{ Sample sizes } \\
\hline & & & \multicolumn{2}{|c|}{ Deciduous } & \multicolumn{2}{|c|}{ Permanent } \\
\hline & & & Teeth & Slices & Teeth & Slices \\
\hline $\begin{array}{l}\text { Fairty } \\
\text { AlGt-3 }\end{array}$ & Ossuary/14th & (Williamson 2014) & 10 & 54 & 10 & 67 \\
\hline $\begin{array}{l}\text { Uxbridge } \\
\text { BbGs-3 }\end{array}$ & Ossuary/15th & (Pfeiffer et al. 2016) & 11 & 62 & 10 & 68 \\
\hline $\begin{array}{l}\text { Kleinburg } \\
\text { AlGv-1 }\end{array}$ & Ossuary/16th & (Williamson 2014) & 10 & 56 & 9 & 60 \\
\hline $\begin{array}{l}\text { Warminster } \\
\quad \text { (Cahiagué) } \\
\text { BdBv-1 }\end{array}$ & Ossuary/17th & $\begin{array}{r}\text { (Mullen 1990; } \\
\text { Sykes 1983) }\end{array}$ & 3 & 21 & 3 & 21 \\
\hline $\begin{array}{l}\text { Maurice } \\
\text { BeHa-1 }\end{array}$ & Ossuary/17th & (Jerkić 1975) & 1 & 6 & 7 & 48 \\
\hline Total & & & 35 & 199 & 39 & 264 \\
\hline
\end{tabular}

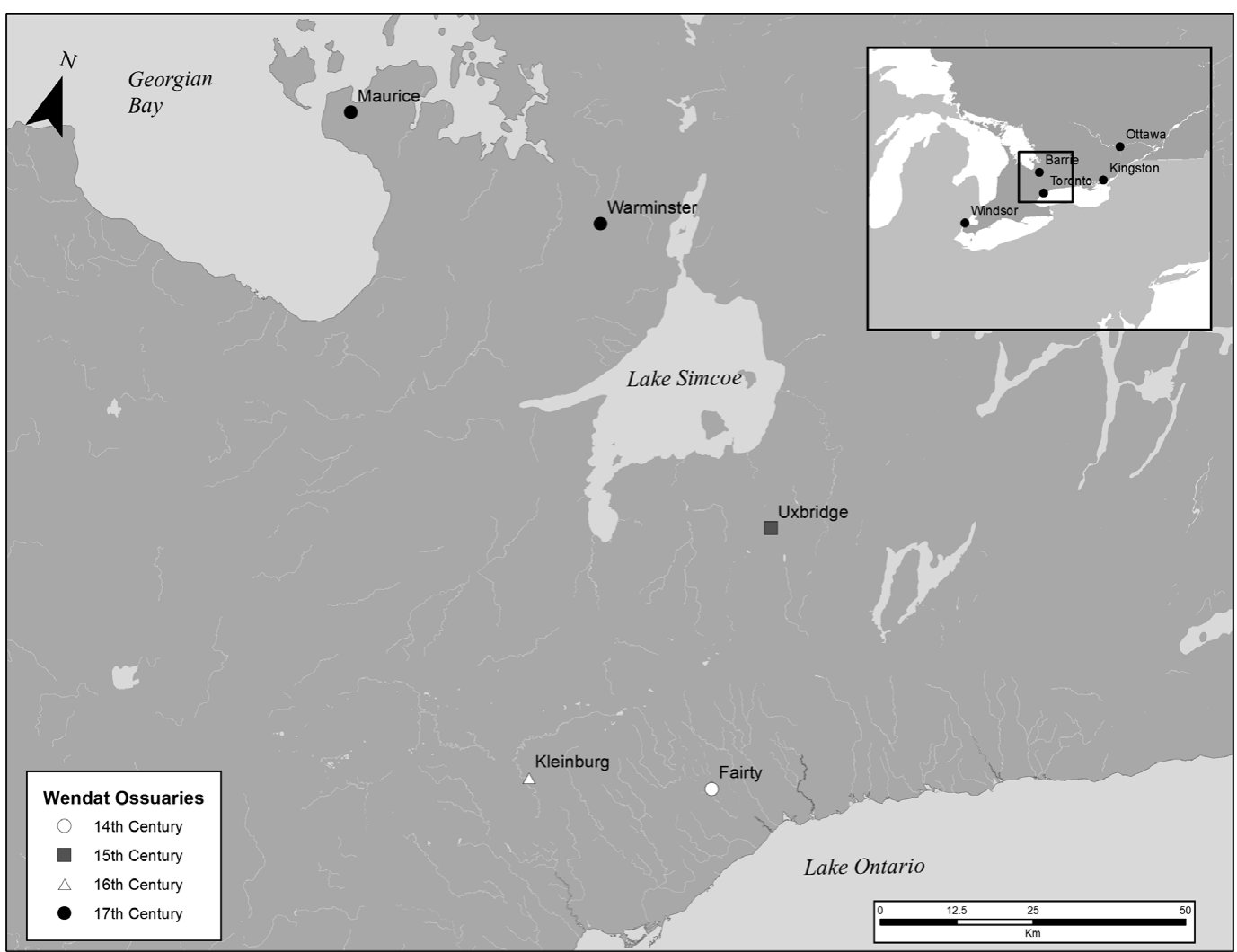

Figure 1. Map of the study region, with archaeological sites identified chronologically. Prepared by Jonas Fernandez, Archaeological Services Inc.

$(p=0.10)$ and A.D. $1387-1638(p=0.90)$ with a median probability of A.D. 1456 (calibrated with CALIB REV7.1.0; Stuiver and Reimer 1993). The AMS date calibrates at two sigma to A.D. $1413-1466(p=0.95)$, with a median probability of A.D. 1437. Recent archaeological work directed by Williamson confirms a contemporaneous 2.5 ha mid-fifteenth-century village named Balthazar is situated $200 \mathrm{~m}$ from the ossuary. 
Excavated in 1970, the Kleinburg ossuary included the remains of at least 561 persons; as above, Pfeiffer and Fairgrieve (1994) summarize previous studies, but no description of the excavation exists. Grave goods, including hundreds of shell discoidal and glass beads, complete iron and brass pots, and other brass and copper artifacts date the ossuary to between A.D. 1580 and 1610 (Williamson 2014:25). The Kleinburg ossuary is associated with the Skandatut site, the last village to have been occupied in the Humber and Don River sequence prior to the movement of the community from the north shore of Lake Ontario to Old Wendake in Simcoe County, the historic homeland of the HuronWendat (Williamson 2014:25). The village site covers 2.6 ha and was surrounded by a one- to two-row palisade. Surface collections from the site also yielded numerous shell beads along with brass scrap and glass beads.

Excavated from 1946 through 1979, the Warminster village consisted of two, probably contemporaneous, palisaded sections approximately $165 \mathrm{~m}$ apart (Sykes 1983). The south village was 2.6 ha in size, while the north was $3.4 \mathrm{ha}$, the latter yielding evidence of the presence of 80 distinct houses (Sykes 1983:81, 85). Trigger (1976:304) discussed the possibility that Warminster was the historically recorded village of Cahiagué, which Samuel de Champlain visited in A.D. 1615. However, Fitzgerald (1986:3-7) argued that the site dates to after A.D. 1620 based on glass bead chronology. Unfortunately, much of the skeletal material from the village's associated ossuary could not be located at the time of repatriation, so our sample of skeletal material for this site is small.

The Maurice ossuary was excavated in 1968 and included the remains of 132 persons (Jerkić 1975), although only 57 could be located at the time of repatriation. The ossuary glass bead assemblage suggests its age lies between A.D. 1630 and 1650 (Jerkić 1969; Motykova 1969).

\section{Deciduous Teeth}

Here we report on a total of 35 mandibular deciduous teeth from the five ossuaries. Thirty-three of the teeth are deciduous first molars $\left(\mathrm{dm}_{1}\right)$; two are deciduous second molars $\left(\mathrm{dm}_{2}\right)$, one each from Warminster and Maurice. The first and second molars came from different mandibles and thus different persons. We have combined the two in the analysis, noting the effect of the $\mathrm{dm}_{2}$ as appropriate (Table 2; Supplemental Table 1).

\section{Permanent Teeth}

Selected for their absence of caries and light occlusal wear (no secondary dentine), the teeth represent adults of both sexes who died in early to mid-adulthood. There are $39 \mathrm{M}_{1}$ teeth from five ossuaries (Table 2; Supplemental Table 2). Twenty-three $\mathrm{M}_{1}$ are from mandibles that were complete enough for sex to be ascertained, based primarily on the mental eminence (Buikstra and Ubelaker 1994:Figure 4). The groupings here include those individuals for whom we could confidently assign sex, as well as those for whom sex assignment was "probable" (see Supplemental Table 2). The samples from the earlier two sites include nine males (a mental eminence score of 4 or 5) and five females (a mental eminence score of 1 or 2). The later three sites include three males and six females.

\section{Methods}

Age estimates used in this study are based on median values from the London Atlas of Tooth Development and Eruption (AlQahtani et al. 2010). Comparisons indicate that the Atlas is superior to earlier dental development charts, including one developed for use with North American aboriginal dental remains (AlQahtani et al. 2014). All teeth were catalogued, photographed, and molded as negative casts. Using a hand-held Dremel saw fitted with an emery cutoff wheel, teeth were cut in half in the vertical plane, from the cleft between the roots to the occlusal surface. One half was set aside for future research. If the two halves had roots of differing lengths, the longer root was preferred for analysis.

Each deciduous tooth was divided into five to seven horizontal slices for analysis, for a total of $199 \delta^{15} \mathrm{~N}$ determinations. Each permanent tooth was divided into a maximum of seven horizontal slices for a total of $264 \delta^{15} \mathrm{~N}$ determinations (Table 2). The coronal dentine beneath the enamel was divided into a maximum of three slices, from the DEJ moving toward the 
Table 2. $\delta^{15} \mathrm{~N}_{\text {dentine }}$ and $\delta^{13} \mathrm{C}_{\text {dentine }}$ Deciduous Tooth Values.

\begin{tabular}{|c|c|c|c|c|c|c|c|c|c|c|}
\hline & & & & $15 \mathrm{~N}(\%)$ & & & & $\delta^{13} \mathrm{C}(\%$ & & \\
\hline & $N$ & & $\begin{array}{l}\text { Decid. } \\
\text { Crown }^{1}\end{array}$ & $\begin{array}{l}\text { Decid. } \\
\text { CEJ }\end{array}$ & $\begin{array}{l}\text { Decid. } \\
\text { apex }\end{array}$ & $\begin{array}{l}\text { Post- } \\
\text { Weaning }\end{array}$ & $\begin{array}{l}\text { Decid. } \\
\text { crown }\end{array}$ & $\begin{array}{l}\text { Decid. } \\
\text { CEJ }\end{array}$ & $\begin{array}{l}\text { Decid. } \\
\text { apex }\end{array}$ & $\begin{array}{l}\text { Post- } \\
\text { Weaning }^{2}\end{array}$ \\
\hline Fairty & 10 & Mean & 14.1 & 14.5 & 12.7 & 11.7 & -9.6 & -9.7 & -10.8 & -10.7 \\
\hline & & s.d. & 1.2 & 0.6 & 0.6 & 0.5 & 1.0 & 0.7 & 0.6 & 1.1 \\
\hline & & & & & & $N=15$ & & & & $N=15$ \\
\hline Uxbridge & 11 & Mean & 14.0 & 14.3 & 13.0 & 11.4 & -9.6 & -9.8 & -10.8 & -10.9 \\
\hline & & s.d. & 0.9 & 0.8 & 0.8 & 0.7 & 1.2 & 0.6 & 1.2 & 0.9 \\
\hline & & & & & & $N=16$ & & & & $N=16$ \\
\hline Kleinburg & 10 & Mean & 13.3 & 14.1 & 12.8 & 11.8 & -10.4 & -10.3 & -11.1 & -10.2 \\
\hline & & s.d. & 1.4 & 1.0 & 0.9 & 0.4 & 1.1 & 0.9 & 1.1 & 0.7 \\
\hline & & & & & & $N=16$ & & & & $N=16$ \\
\hline Warminster & 3 & Mean & 15.0 & 14.9 & 14.0 & 11.9 & -10.7 & -11.6 & -12.6 & -10.5 \\
\hline & & s.d. & 0.4 & 1.6 & 2.1 & 0.5 & 1.9 & 1.9 & 1.4 & 0.9 \\
\hline & & & & & & $N=6$ & & & & $N=6$ \\
\hline Maurice & 1 & Mean & 14.4 & 13.2 & 12.5 & 12.7 & -9.5 & -9.8 & -9.5 & -10.5 \\
\hline & & s.d. & 0.7 & & & 1.2 & 0.1 & & & 0.7 \\
\hline & & & & & & $N=8$ & & & & $N=8$ \\
\hline TOTALS & & Mean & 14.0 & 14.3 & 12.9 & & -10.1 & -10.1 & -11.0 & \\
\hline & & s.d. & 1.2 & 0.9 & 1.0 & & 1.1 & 1.0 & 1.1 & \\
\hline
\end{tabular}

${ }^{1}$ Values incorporate all slices from beneath the enamel.

${ }^{2}$ Presumptive adult apical values from permanent teeth of their community (Pfeiffer et al. 2016).

cemento-enamel junction (CEJ). The attempt to divide the dentine beneath the enamel into multiple slices was not consistently successful, so the number of data points from coronal dentine is variable. The other slices represent tissue moving from CEJ to apex.

The enamel was removed, in most cases by grinding it away with a diamond-tipped dental drill bit attached to the Dremel device. The resulting enamel powder was saved for further analysis. In some cases, fragments of enamel could be broken cleanly away from the dentine. The tooth root was lightly abraded to remove cementum and any surface contamination. A few samples appeared brittle and in danger of breaking up because of vibrations from the drill. On these, we left the occlusal enamel in place, to be removed after demineralization when the softened dentine could be cut away without risk of fragmenting the specimen.

The dentine was weighed before being placed in dilute hydrochloric acid $(\mathrm{HCl})(0.5 \mathrm{M}$ for larger, more robust specimens, $0.3 \mathrm{M}$ for those that appeared brittle or fragile). The acid was changed every day and the progressive demineralization of the samples was monitored visually, assessed through the increasing softness and flexibility of the dentine. When no hard core of mineralized tissue remained, the acid was poured off, the samples rinsed in distilled water and treated overnight in $0.1 \mathrm{M} \mathrm{NaOH}$ to remove humic contaminants, then rinsed again in distilled water. Next, the demineralized dentine was cut with a scalpel into a maximum of seven horizontally oriented slices: three from beneath the crown and four from the CEJ to the apex.

The work was completed between 2013 and 2014. In 2013, only deciduous molars were included. The dentine beneath the crown was labeled as slices 1 and 2, but isotopic values for those two slices have been averaged to provide a single observation. The subsequent four slices represent the dentine from the CEJ to the root apex, which were labeled 3 through 6. In 2014, both deciduous and permanent teeth were included in the study. The dentine beneath the crown was separated into a maximum of three slices: 1A, 1B, 1C. The subsequent slices were labeled 2 through 5 . Because of difficulties separating dentine from enamel, varying numbers of crown slices were obtained in both years (Figure 2).

The slices were soaked in distilled water, changed daily, until the $\mathrm{pH}$ remained neutral, and 


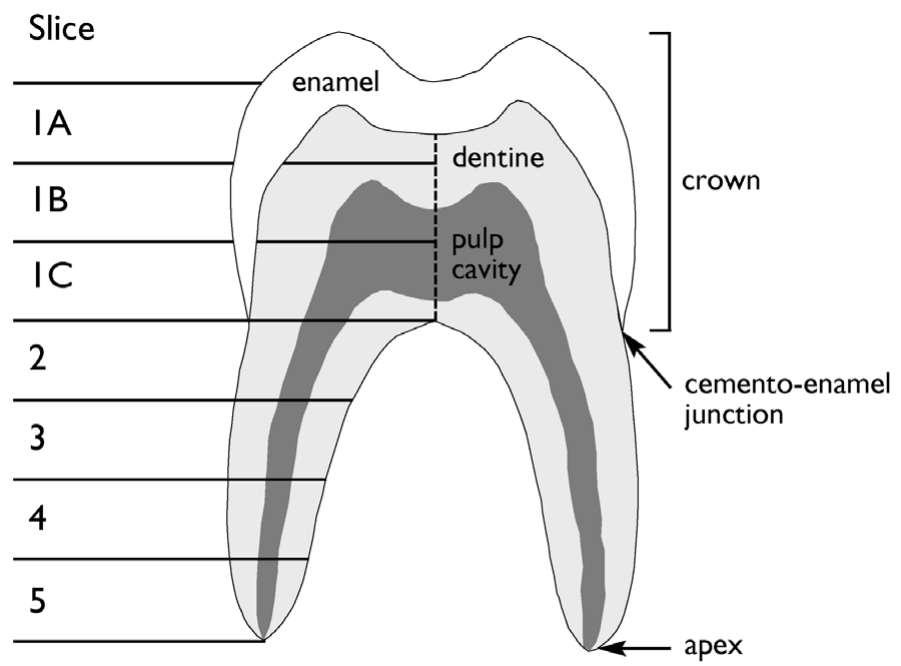

Figure 2. Diagram illustrating the sampling strategy employed and labeling anatomical features that are discussed in the text. Prepared by Neil Rusch.

then freeze-dried. The weight of each slice was recorded, but given that there were sometimes slight losses of material during slicing, it is not possible to calculate precise weight percentage collagen yields.

In this study, the demineralized tooth roots consisted of springy, well-preserved collagen that retained the size and shape of the original samples. No rootlets or other macrocontaminants were observed. $\% \mathrm{C}, \% \mathrm{~N}$ and $\mathrm{C} / \mathrm{N}$ ratios reported in Supplemental Tables 1 and 2 attest to this good preservation. We therefore considered it unnecessary to solubilize and filter the collagen, and simply proceeded to combust the dentine slices for analysis (Sealy et al. 2014).

Approximately $0.4 \mathrm{mg}$ of each dentine slice was weighed into a tin cup and combusted at $1020^{\circ} \mathrm{C}$ in a Flash 2000 organic elemental analyzer. The $\mathrm{CO}_{2}$ and $\mathrm{N}_{2}$ gases produced were purified and swept in a stream of helium gas through a Conflo IV interface into a Delta V Plus isotope ratio mass spectrometer (Thermo Scientific, Germany).

Results are expressed in the delta notation relative to air (for nitrogen) or Vienna PeeDee Belemnite (for carbon), where $\delta^{15} \mathrm{~N}=$ $\left({ }^{15} \mathrm{~N} /{ }^{14} \mathrm{~N}_{\text {sample }} /{ }^{15} \mathrm{~N} /{ }^{14} \mathrm{~N}_{\text {standard }}-1\right) \times 1000 \%$; $\delta^{13} \mathrm{C}$ is calculated in the same way, using the isotope pair ${ }^{13} \mathrm{C} /{ }^{12} \mathrm{C}$. In-house standards of Merck gelatine, seal bone and valine were analyzed with each batch of samples. Repeated analyses of these standards yielded standard deviations of less than $0.2 \%$ for both nitrogen and carbon.

\section{Results}

\section{Deciduous Teeth}

The deciduous teeth generally demonstrate declining $\delta^{15} \mathrm{~N}_{\text {dentine }}$ from crown to apex. The mean value for dentine from crown samples is $\delta^{15} \mathrm{~N}_{\text {dentine }} 14.0 \%$ o $( \pm 1.2 \%$, range from 16.8 to $11.1 \%$ ), and that for the apex samples is $\delta^{15} \mathrm{~N}_{\text {dentine }} 12.8 \%$ o $( \pm 0.8 \%$, range from 14.1 to $11.4 \%$, excluding a single outlier [Warminster 16023 at $16.1 \%$ ]) (Supplemental Table 1). There is no detectable pattern of directional change in $\delta^{15} \mathrm{~N}$ values from the DEJ to the CEJ. In almost all teeth, there is a gradual decline in enrichment from CEJ to apex, suggesting that the weaning process began during the period of $\mathrm{dm}_{1}$ development. One tooth (Fairty 16041) shows a very abrupt decline in $\delta^{15} \mathrm{~N}$, consistent with rapid weaning, and one (Warminster 16023) shows the maintenance of a very enriched $\delta^{15} \mathrm{~N}$ pattern from CEJ to apex (Figure 3).

Deciduous crown values represent diet at 6 to 8 months of age, while apex values represent diet at 2 to 2.5 years of age. Most apical values do 
Fairty

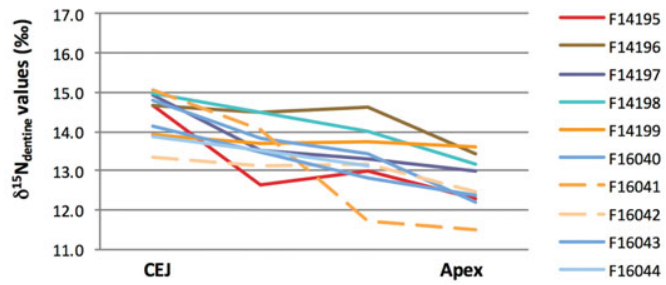

Uxbridge
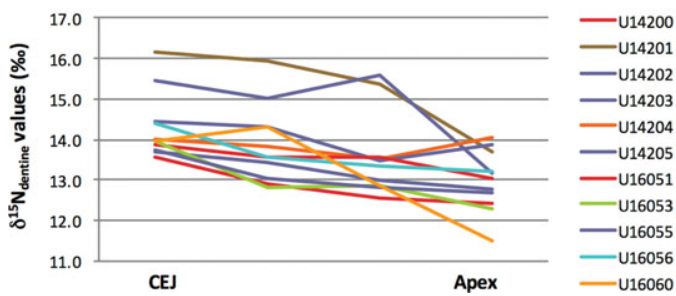

Kleinburg

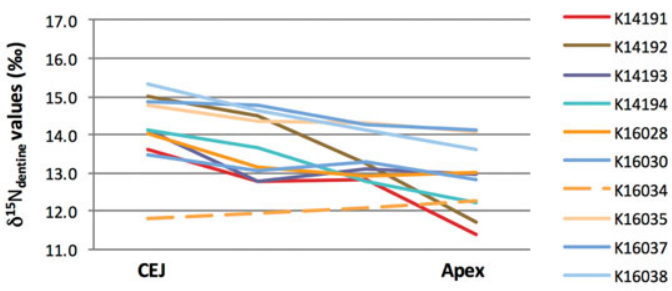

Warminster and Maurice

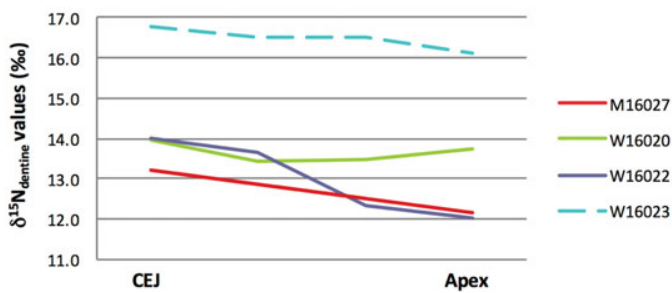

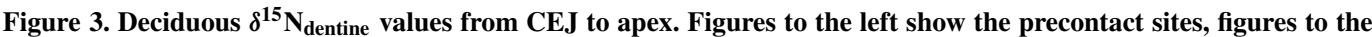
right show the postcontact sites. The two $\mathbf{d m}_{2}$ teeth are included in the latter. Dashed lines indicate weak or absent breastfeeding signal (Fairty 16042, Kleinburg 16034); abrupt weaning (Fairty 16041); little or no evidence of non-breast milk food sources (Warminster 16023). (Color online)

not reach the expected post-weaning $\delta^{15} \mathrm{~N}$ values (Table 2). This indicates that most children were not fully weaned by 2 to 2.5 years. The collective apical value of the deciduous teeth is $\delta^{15} \mathrm{~N}_{\text {dentine }}$ $12.8 \%$ o $( \pm 0.8 \%$, not including the anomalously enriched Warminster child). The collective average from permanent tooth apices is $\delta^{15} \mathrm{~N}_{\text {dentine }}$ $11.9 \%$ o $( \pm 0.8 \%$ o). These values come from tissue formed in mid-childhood ( 8 to 10 years), but they can confidently be characterized as postweaning dietary indicators. Apical $\delta^{15} \mathrm{~N}$ values of permanent teeth are significantly less enriched than the $\delta^{15} \mathrm{~N}$ values of deciduous teeth (MannWhitney $\mathrm{Z}=4.51, p<0.0001$ ).

Five of 33 deciduous first molars achieved post-weaning isotope values of their community by the time the apex was formed. Two of 21 deciduous first molars from the earlier sites of Fairty and Uxbridge had achieved a postweaning value, while three of 12 deciduous first molars from the later (Euro-contact) sites show post-weaning values at the apex. The apex of one of the two $\mathrm{dm}_{2}$ teeth reached the postweaning community average. The deciduous $\delta^{15} \mathrm{~N}_{\text {dentine }}$ values suggest that weaning may have proceeded slightly more quickly in communities that were affected by the presence of Europeans.
Table 3. $\delta^{15} \mathrm{~N}_{\text {dentine }}$ and $\delta^{13} \mathrm{C}_{\text {dentine Values of Two }}$ Deciduous Teeth.

\begin{tabular}{llll}
\hline $\begin{array}{l}\text { Catalog } \\
\text { Number }\end{array}$ & $\begin{array}{l}\delta^{15} \mathrm{~N}(\%) \\
\text { range }\end{array}$ & $\begin{array}{l}\delta^{13} \mathrm{C}(\%) \\
\text { range }\end{array}$ & $\begin{array}{l}\text { Approx. age } \\
\text { at death }\end{array}$ \\
\hline F16042 & 12.5 to 13.3 & -11.4 to -8.3 & $\sim 6$ yr. \\
K16034 & 11.1 to 12.2 & -10.8 to -9.4 & unknown \\
\hline
\end{tabular}

The data set includes two deciduous teeth that bear no clear signal of breastfeeding: Fairty 16042 and Kleinburg 16034. Their initial $\delta^{15} \mathrm{~N}$ values are low, and throughout tooth development they show change of $1 \%$ or less. The $\delta^{13} \mathrm{C}$ values of these two teeth are also quite stable. Kleinburg 16034 shows consistently positive $\delta^{13} \mathrm{C}$ values that could represent maize gruel, but Fairty 16042 shows quite variable $\delta^{13} \mathrm{C}$ values (Table 3). If these infants were not breastfed, alternative foods seem to have varied on a caseby-case basis, perhaps including chewed foods or watery maize gruel as described above.

With regard to $\delta^{13} \mathrm{C}$ values more generally, the magnitude of the expected trophic enrichment is smaller, so the information is less clear. With the exception of the three quite variable teeth from Warminster, all deciduous apical means are within one standard deviation of their community's post-weaning value. 
Table 4. $\delta^{15} \mathrm{~N}_{\text {dentine Values of Crown, Cemento-Enamel }}$ Junction, and Apical Slices of Permanent Teeth.

\begin{tabular}{lllrrr}
\hline & & & \multicolumn{3}{c}{$\delta^{15} \mathrm{~N}(\%)$} \\
\cline { 4 - 6 } & \multirow{2}{*}{$N$} & & Crown & CEJ* & Apex \\
\hline Fairty & \multirow{2}{*}{10} & Mean & 12.2 & 11.2 & 11.6 \\
& & s.d. & 1.7 & 0.6 & 0.6 \\
Uxbridge & \multirow{2}{*}{10} & Mean & 13.1 & 11.1 & 11.4 \\
& & s.d. & 1.2 & 0.5 & 0.7 \\
Kleinburg & \multirow{2}{*}{ N } & Mean & 11.8 & 11.5 & 11.9 \\
& & s.d. & 0.9 & 0.5 & 0.3 \\
Warminster & \multirow{2}{*}{3} & Mean & 12.5 & 11.8 & 11.9 \\
& & s.d. & 0.8 & 0.2 & 0.5 \\
Maurice & 7 & Mean & 12.2 & 12.3 & 13.0 \\
& & s.d. & 1.1 & 1.2 & 0.8 \\
Total & & Mean & 12.4 & 11.4 & 11.9 \\
& & s.d. & 1.3 & 0.8 & 0.8 \\
\hline
\end{tabular}

*Cemento-enamel junction.

\section{Permanent Teeth}

The isotopic results from the deciduous teeth indicate that for most children, weaning was still underway at the time when $\mathrm{dm}_{1}$ formation was complete. Therefore, permanent teeth were assessed to see if the end point of the weaning process could be identified. This approach has the advantage of focusing on people who survived early childhood. Persons who were fully weaned prior to 2.5 years of age will show no enrichment to the dentine of their permanent molar crown.

Summary statistics of permanent first molars demonstrate greater variability in coronal values than in apical values (Levene test $\mathrm{F}=11.08$, $p<0.01)$. At four of the five sites the permanent coronal values are, on average, less enriched than the apical values of the deciduous teeth from those sites (Table 2). The higher variability in values for coronal dentine, compared to CEJ and apex values, indicates that some permanent tooth crowns were formed after weaning was complete and some were formed while the process was still underway (Table 4).

To assess what proportion of the permanent teeth show the enrichment of breast milk, the $\delta^{15} \mathrm{~N}$ value of the most coronal slice of each permanent crown (slice 1A or equivalent) was compared with that of the mid-root (slice 4). If the crown value is enriched by at least $1 \%$ relative to the mid-root, we infer that the weaning process was not complete when the coronal dentine was being formed. Among the 20 permanent teeth from the two earliest sites (Fairty and Uxbridge), 13 show enrichment of greater than $1 \%$ at the DEJ compared to the mid-root dentine. That is, weaning was not completed while the permanent crown was forming. Among the 19 permanent teeth from the three later sites, three show the degree of enrichment in the coronal dentine (one from each of the sites). The other 16 permanent molars show steady state, consistent with the dentine having been formed after weaning was completed (Figure 4). This difference in pattern is statistically significant $\left(X^{2}=9.73, p<.01\right)$ and indicates that a higher proportion of people from the more recent sites had been weaned by 2 to 2.5 years of age. If a wider spacing of $1.5 \%$ is applied, the ratios are 10 of 20 in the earlier sites, and two of 19 in the later sites; the difference remains significant $\left(X^{2}=7.14, p<.01\right)$.

\section{Maternal and Post-weaning Diet}

Prior study of available dietary protein sources has demonstrated a broad range of $\delta^{15} \mathrm{~N}$ values among candidate foods. Pfeiffer et al. (2016:527) report white-tailed deer (Odocoileus virginianus) have a mean value of $\delta^{15} \mathrm{~N}_{\text {dentine }} 6.2 \pm 1.0 \%$ $(n=55)$, and bone collagen values from fish species show a range from values comparable to that of deer to over $12 \%$ for Salmonidae and cod. Plant foods have lower values. Warinner et al. (2013) report mean $\delta^{15} \mathrm{~N}$ of $4.1 \pm 2.5 \%$ $(n=17)$ and $3.7 \pm 2.0 \%$ o $(n=8)$ for beans and maize respectively, cautioning that values are influenced by different styles of cultivation. As their babies' teeth formed, mothers would have been exploiting varying resources, perhaps on a seasonal basis. This would lead to variability in $\delta^{15} \mathrm{~N}$ of breast milk and the dentine of deciduous teeth.

This suggestion is reinforced by the patterns in permanent tooth dentine. The plots of permanent teeth distinguished by sex (Figure 5) illustrate a difference, in which there is variability of post-weaning $\delta^{15} \mathrm{~N}$ values among females, and rather homogeneous, slightly less enriched, postweaning values among males. This may indicate more diverse protein sources in women's diets, and more consistent consumption of protein with lower $\delta^{15} \mathrm{~N}$, such as deer meat and beans, among men. At the least, there appears to have been 


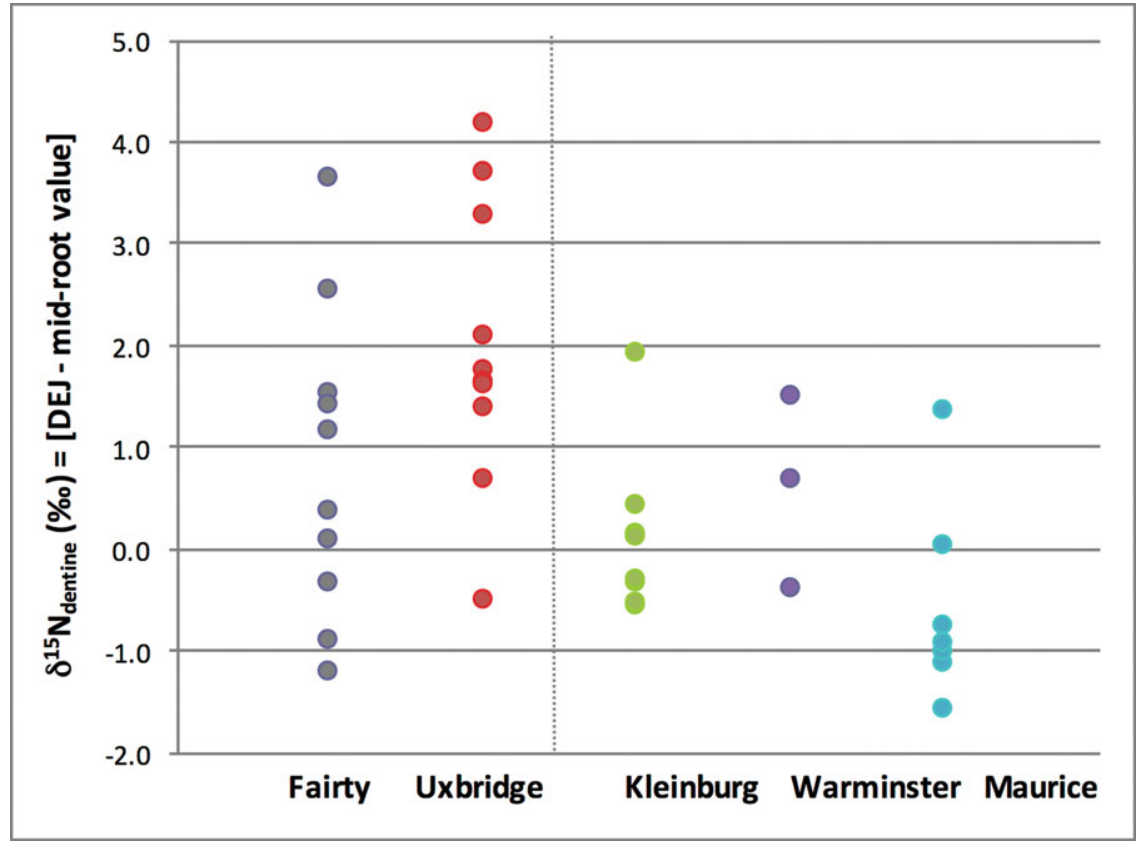

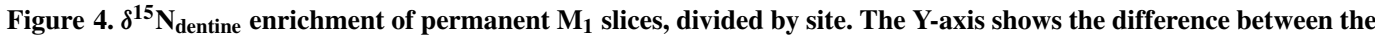
most coronal slice (DEJ) versus the mid-root value. Sites are organized chronologically, from earliest to latest. Values at zero or negative indicate that weaning was complete prior to the initiation of dentine formation within the $M_{1}$. The shaded vertical dotted line reflects the statistically significant difference between values from earlier and later sites. (Color online)

a difference in protein availability for boys and girls in mid-childhood, when the root dentine was forming. The mean apical $\delta^{15} \mathrm{~N}_{\text {dentine value for the }}$ 12 males is $\delta^{15} \mathrm{~N}_{\text {dentine }} 11.7$ ( $\pm 0.5 \%$; range 11 to $12.8 \%)$; for the 11 females it is $11.9( \pm 1.1 \%$; range 10.5 to $14.2 \%$ ). The mean values do not differ statistically, but the male apices show significantly less isotopic variation (Levene test $\mathrm{F}=4.42, p=0.05)$. The mean $\delta^{15} \mathrm{~N}_{\text {dentine }}$ value for apices from the other 16 teeth is $\delta^{15} \mathrm{~N}_{\text {dentine }}$ $12.1( \pm 0.7 \%)$. A standard deviation that is intermediate between the males and females would be expected if the latter group includes teeth from both sexes.

It is plausible that childhood marked the beginning of a lifelong effect of gender on diet. Of the 23 teeth attributed by sex, we have bone values for six of the females and six of the males (Pfeiffer et al. 2016). Comparing the $\delta^{15} \mathrm{~N}_{\text {bone }}$ values, the females are $13.2( \pm 1.8 \%$ o $)$ and the males are $12.4( \pm 1.4 \%$ o). These are small samples and the difference is not significant $(t=0.88, p=0.40)$ but the trend is in the same direction as the tooth roots, with females showing higher and more variable $\delta^{15} \mathrm{~N}$ values than males. This is consistent with the idea that males had more access to venison and/or other sources of terrestrial protein.

The $\delta{ }^{13} \mathrm{C}$ values of candidate protein sources are more tightly clustered. For example, mean $\delta^{13} \mathrm{C}_{\text {dentine }}$ in deer of the region is $\delta^{13} \mathrm{C}_{\text {dentine }}$ of $-22.3 \pm 0.9 \%$, and for Salmonidae $(n=17)$ mean $\delta^{13} \mathrm{C}=-20.1 \pm 0.84 \%$ (Pfeiffer et al. 2016). As might be expected, in the context of the small trophic offset and a clustering of candidate food $\delta^{13} \mathrm{C}$ values, $\delta^{13} \mathrm{C}_{\text {dentine values for }}$ the permanent teeth from males and females in this study show no discernible differences.

\section{Discussion and Conclusions}

\section{Huron-Wendat Infant Feeding Practices in Contemporary Perspective}

Many contemporary authorities identify an age of about 6 months postpartum as desirable for the introduction of supplementary foods (Health Canada 2016; WHO 2016). In recent 


\section{All Females}
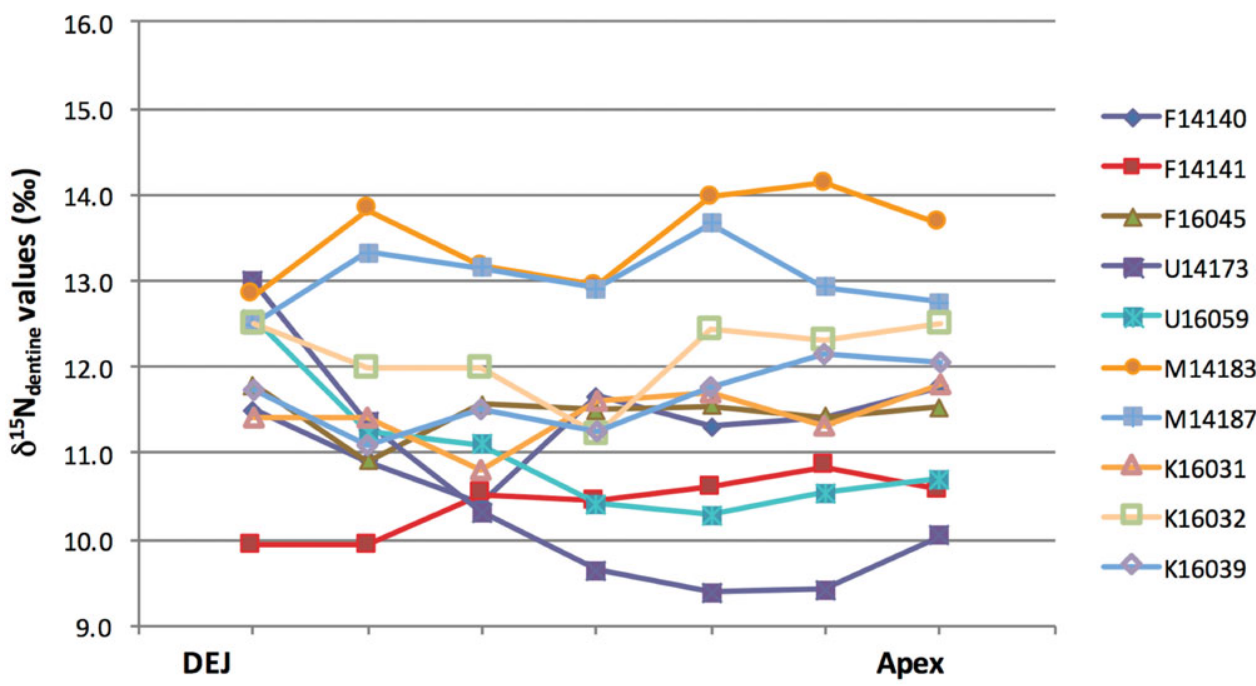

All Males

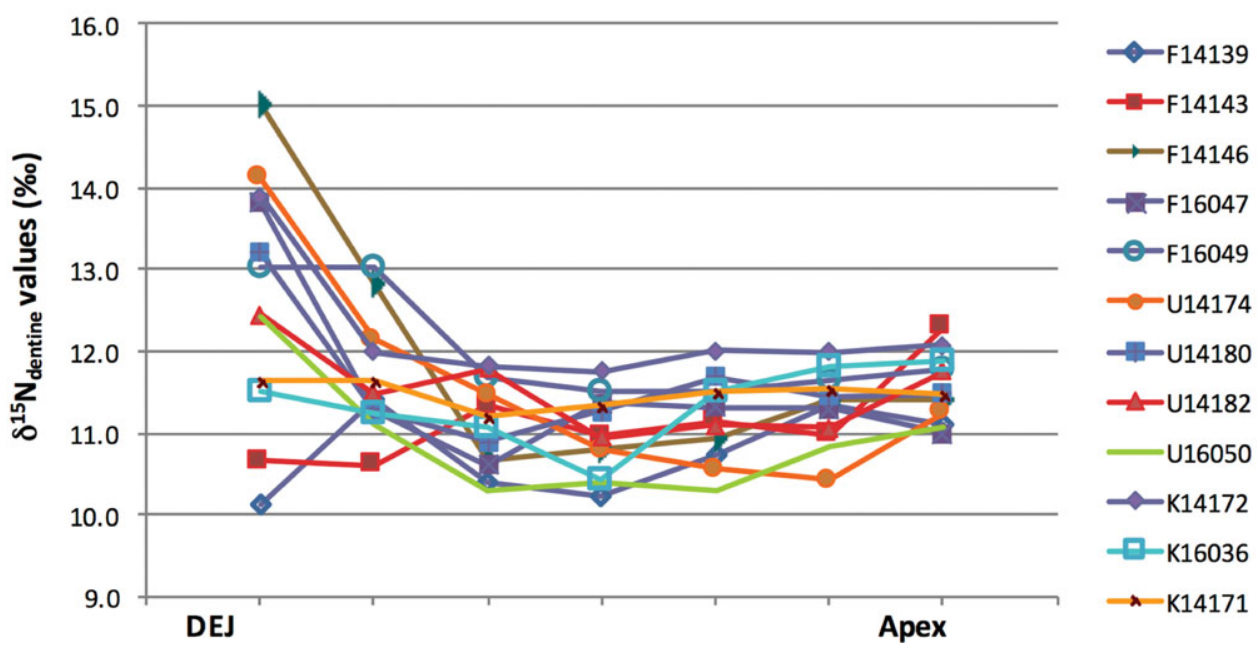

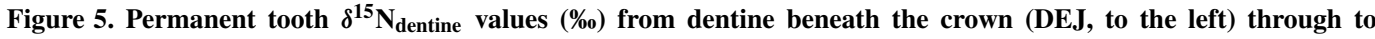
the root apex (right). Sex was ascertained from mandibular shape, mainly the mental eminence. The categories include mandibles where sex attribution is tentative. Teeth are labeled by site: $F=F a i r t y, U=U x b r i d g e, ~ M=M a u r i c e$, $\mathrm{K}=$ Kleinburg. (Color online)

nonindustrialized communities, some solid food was introduced on average at 5 months (Humphrey 2010). This age corresponds with completion of the $\mathrm{dm}_{1}$ crown, which has been noted as 5.5 months (Hillson 1996:Table 5.2), or between 4.5 and 7.5 months (AlQahtani et al. 2010, Table 3). The mean $\delta^{15} \mathrm{~N}_{\text {dentine }}$ value for $\mathrm{dm}_{1}$ crowns in this study is $14.0 \%$ o (Table 2). The value for permanent molar apices (reflecting post-weaning diet) is $11.9 \%$ (Table 4$)$. Given the working assumption that breastfeeding enriches $\delta^{15} \mathrm{~N}$ by $2 \%{ }_{0}-3 \%$, Huron-Wendat mothers were not introducing notable proportions of supplementary foods prior to about 5 to 6 months postpartum. The only weaning food mentioned ethnographically is maize gruel, ingestion of which would be reflected in lower $\delta^{15} \mathrm{~N}_{\text {dentine }}$ values. Candidate protein sources that could 
replace breast milk have a wide range of $\delta^{15} \mathrm{~N}$ values (Pfeiffer et al. 2016). To maintain the level of enrichment seen in this study, weaning food would need to preferentially incorporate high trophic level fish such as burbot (cod) and salmon.

With regard to completion of the weaning process, averages for diverse human groups cluster around 27 to 30 months (Humphrey 2010; Sellen and Smay 2001). This is about the same time as the completion of the apex of a $\mathrm{dm}_{1}$ (2.3 years according to Hillson 1996, 2.5 years per London Atlas). Some, but not all, Huron-Wendat children had been weaned by the time that this maturational landmark was achieved. Relative to modern global values, the difference between precontact and postcontact Huron-Wendat groups is within the range of usual practice.

This study of an established community of horticulturists is not consistent with the idea that weaning was completed early among agricultural groups. Neither the initiation nor the completion of the weaning process appears to have been rapid, relative to other past and present human groups. This study does not support the idea that the increase in Huron-Wendat population size was associated with early weaning of infants.

\section{Huron-Wendat Infant Feeding Practices}

The weaning process can be viewed as stages, from exclusive breastfeeding to the introduction of some weaning foods, moving toward a diet of some combination of breast milk, complementary foods, and family foods. Ultimately, the child completes the transition to a diet like that of the adults of her/his community. The pace at which this transition occurs is determined at least initially by the mother. The deciduous teeth studied here provide information on the probable timing of the first transition. Isotopic enrichment at the deciduous CEJ is comparable to that of the coronal dentine (Table 2), but mean apical values decline somewhat. This suggests that reliance on complementary foods was not established until after formation of CEJ dentine. This is at the stage of root initiation, which for the $\mathrm{dm}_{1}$ occurs at a range between 7.5 and 18 months of age (AlQahtani et al. 2010). Deciduous apical enrichment indicates that most children continued to be breastfed beyond $\mathrm{dm}_{1}$ apex completion, at an age of about 2 to 2.5 years.

The $\delta^{15} \mathrm{~N}$ values of permanent tooth coronal dentine $(12.4 \pm 1.3 \%$ ) are very similar to those of the deciduous apices $(12.9 \pm 1.0 \%$ o). The permanent tooth coronal values are somewhat enriched on average, and they show more variability than their apical values. These facts suggest that for many but not all children breast milk continued to be part of their diet after two years. By the age at which the permanent CEJ dentine was formed, the childhood diet did not include an appreciable amount of breast milk. This is at the stage of root initiation, which is the median formation stage of $\mathrm{M}_{1}$ at age 3.5 years (AlQahtani et al. 2010). The weaning process began at some time between 7.5 and 18 months, and was complete in all cases by 3.5 years. $^{1}$

About half of the permanent teeth can be explored for sex differences. We note that plots of apical $\delta^{15} \mathrm{~N}_{\text {dentine values from sex-assigned }}$ $\mathrm{M}_{1}$ show a sex-based difference in childhood diet. Boys had access to a higher proportion of low trophic level protein (presumably deer), and girls had access to a higher proportion of higher trophic level protein (presumably diverse types of fish). The import of these observations is tempered by the fact that the earlier sites at which weaning was completed later provided the larger proportion of male permanent teeth. This somewhat unbalanced study design weakens observations relating to sex/gender. Nevertheless, differences in childhood diets are plausible.

A possible explanation may be that at early ages, boys and girls were introduced to their future gender-related roles in the community (Tooker 1964:124-125). Boys may have gone with men to hunt deer, to collect wood for construction and maintenance of palisades and other structures, and to clear land for agricultural fields. Women may have introduced girls to the manufacture of pottery, collection of wild plants, and the planting, tending, and harvesting of horticultural crops. These tasks occurred closer to the villages. Villages' proximity to streams would have made some types of fish readily available.

These isotopic results contribute to a developing literature that demonstrates the impressive potential of this research protocol through which 
we can test evolutionary models (for example Charnov 1993; Kaplan 2000) as well as contribute to our understanding of specific culture histories. The results reported here are based on larger numbers of teeth than most prior studies using the horizontal dentine slice protocol, and this work integrates valuable information available from the deciduous teeth in a novel way. Huron-Wendat boys and girls consumed different diets during childhood, similar to California hunter-gatherer communities (Eerkens and Bartelink 2013; Greenwald et al. 2016). This study offers intriguing insights into the lives of ancestral Huron-Wendat infants and children, and thereby the whole community.

\section{The Impact of Cultural Disruption}

The samples of deciduous and permanent teeth show differences when considered site-by-site. A suggestive pattern in which earlier sites show more enrichment of deciduous tooth roots is consistent with the statistically significant difference in weaning patterns seen in permanent teeth. There is no discernible difference in the timing of introduction of weaning foods, but those archaeological sites that date to after the arrival of Europeans show earlier completion of the weaning process. The magnitude of this shift appears to have been a few months, with weaning of precontact children completed by around 2.5 to 3 years and postcontact children weaned by around 2 to 2.5 years of age. This pattern applies to Kleinburg, where European artifacts confirm indirect contact, and to the two more recent sites that were situated in Simcoe County (Old Wendake). The precise date of Warminster is debated, so it is difficult to link our results to specific documented events. The Maurice values may be related to the stress felt by HuronWendat populations during A.D. 1630-1650, when they suffered a serious population decline due to European-introduced diseases (Warrick 2008) and there was regular threat of attack from Haudenosaunee populations (Williamson 2014:38-42).

After contact with Europeans, the proportion of maize in the Huron-Wendat diet increased (Pfeiffer et al. 2016). This may reflect scarcity of meat and fish, perhaps because normal fishing and hunting activities were disrupted by the lack of sufficient numbers of people to hunt and to fish at lakes far from the village, at least after the epidemics beginning in the mid-1630s (Warrick 2008:222-227). Thus, the Huron-Wendat turned back to maize, a food source near the village. If there was general dietary insufficiency, women may have chosen to conserve their own energy stores by weaning their children at slightly younger ages. While we would not necessarily expect the Kleinburg community to have suffered the stresses of direct contact (such as disease transmission), their social and political lives were clearly in transition at the time, as the community leaders were no doubt considering moving from the north shore of Lake Ontario to Old Wendake and participating in the Wendat confederacy (Williamson 2014:14-15). Research on contemporary human populations has linked caregiver distress to childhood under-nutrition (Hadley et al. 2012; Pereira and Hodge 2015). Studies of dietary indicators from ancestral Huron-Wendat people provide strong suggestions of the distress that contact may have caused, leading to earlier completion of weaning and a lower proportion of protein in the general diet. Through analogies with the effects of global sociopolitical disruptions today, we can have a better sense of how such dramatic changes affected past lives of the Huron-Wendat and even their decision processes.

Acknowledgments. This research was undertaken in collaboration with the Huron-Wendat Nation of Wendake, Québec. These research results have been shared with them. We thank the students and teaching assistants who participated in the University of Toronto Science Abroad program in 2013 and 2014: Amy Beresheim, Gina Carroll, Jenna Coutinho, Alanna Leale, Natasha Leclerc, Nicole Legro, Stephanie Lulka, and Zihang (Danny) Pan. We received support from staff and postgraduate students at the University of Cape Town, including John Lanham, Julie Luyt, and Ian Newton. The figures were prepared by Jonas Fernandez, Neil Rusch, and Jennifer Newton. We thank Luseadra McKerracher and Elizabeth Sawchuk for input during preparation of the document. Sealy acknowledges support from the South African Research Chairs Initiative of the National Research Foundation and the Department of Science and Technology. We also are grateful for the helpful comments of three anonymous reviewers.

Data Availability Statement. All the data generated in this study are included in the supplementary tables.

Supplemental Materials. Supplemental materials are linked to the online version of the paper, accessible at https://doi. org/10.1017/aaq.2016.36. 
Supplemental Table 1. Isotope Values for Deciduous Teeth. Teeth

Supplemental Table 2. Isotope Values for Permanent

\section{References Cited}

AlQahtani, Sakher J., M. P. Hector, and H. M. Liversidge 2010 Brief Communication: The London Atlas of Human Tooth Development and Eruption. American Journal of Physical Anthropology 142:481-490.

2014 Accuracy of Dental Age Estimation Charts: Schour and Massler, Ubelaker, and the London Atlas. American Journal of Physical Anthropology 154:7078

Anderson, James E.

1963 The People of Fairty: An Osteological Analysis of an Iroquois Ossuary. National Museum of Canada Bulletin 193:28-129.

Beaumont, Julia, Andrew Gledhill, Julia A. Lee-Thorp, and Janet Montgomery

2012 Childhood Diet: a Closer Examination of the Evidence from Dental Tissues Using Stable Isotope Analysis of Incremental Human Dentine. Archaeometry 55:277-295.

Biggar, Henry P. (editor)

1922-1936 The Works of Samuel de Champlain. 6 vols. Champlain Society, Toronto.

Birch, Jennifer, and Ronald F. Williamson

2013 The Mantle Site: An Archaeological History of an Ancestral Wendat Community. AltaMira Press, Lanham, Maryland.

Bocquet-Appel, Jean-Pierre

2011 When the World's Population Took Off: The Springboard of the Neolithic Demographic Transition. Science 333(6042):560-561.

Buikstra, Jane.E. and Douglas H. Ubelaker (editors)

1994 Standards for Data Collection from Human Skeletal Remains. 1st ed. Arkansas Archeological Survey Research Series No. 44. Fayetteville.

Burt, Nicole M.

2015 Individual Dietary Patterns during Childhood: An Archaeological Application of a Stable Isotope Microsampling Method for Tooth Dentin. Journal of Archaeological Science 53:277-290.

Burt, Nicole M., and Sandra Garvie-Lok

2013 A New Method of Dentine Microsampling of Deciduous Teeth for Stable Isotope Ratio Analysis. Journal of Archaeological Science 40:3854-3864.

Charnov, Eric L.

1993 Life History Invariants: Some Explorations of Symmetry in Evolutionary Ecology. Oxford University Press, Oxford.

Clayton, Fiona H., Judith Sealy, and Susan Pfeiffer

2006 Weaning Age among Foragers at Matjes River Rock Shelter, South Africa, from Stable Nitrogen and Carbon Isotope Analyses. American Journal of Physical Anthropology 129:311-317.

Dupras, Tosha

2010 The Use of Stable Isotope Analysis to Determine Infant and Young Child Feeding Patterns. In Human Diet and Nutrition in Biocultural Perspective, edited by Tina Moffat and Tracey Prowse, pp. 89-108. Studies of the Biosocial Society, Catherine Panter-Brick, general editor. Berghahn Books, New York.
Dupras, Tosha, and Matthew W. Tocheri

2007 Reconstructing Infant Weaning Histories at Roman Period Kellis, Egypt Using Stable Isotope Analysis of Dentition. American Journal of Physical Anthropology 134:63-74.

Eerkens, Jelmer W., and Eric J. Bartelink

2013 Sex-Biased Weaning and Early Childhood Diet among Middle Holocene Hunter-Gatherers in Central California. American Journal of Physical Anthropology 152:471-483.

Eerkens, Jelmer W., Ada G. Berget, and Eric J. Bartelink

2011 Estimating Weaning and Early Childhood Diet from Serial Micro-Samples of Dentin Collagen. Journal of Archaeological Science 38:31013111 .

Eerkens, Jelmer W., Kelli Sullivan, and Alexandra M. Greenwald

2016 Stable Isotope Analysis of Serial Samples of Third Molars as Insight into Inter- and Intra-individual Variation in Ancient Diet. Journal of Archaeological Science:Reports 5:656-663.

Fitzgerald, William R.

1986 Is the Warminster Site Champlain's Cahiagué? Ontario Archaeology 45:3-8.

Fogel, Marilyn L., Noreen Tuross, and Douglas W. Owsley 1989 Nitrogen Isotope Tracers of Human Lactation in Modern and Archaeological Populations. Carnegie Institution of Washington Yearbook 88:11117. Carnegie Institution, Washington, D.C.

Forrest, Crystal

2010 Iroquoian Infant Mortality and Juvenile Growth, 1250 to 1700 A.D. Unpublished Ph.D. dissertation, Department of Anthropology, University of Toronto, Toronto, Ontario, Canada.

Fuller, Benjamin T., James L. Fuller, David A. Harris, and Robert E. M. Hedges

2006 Detection of Breastfeeding and Weaning in Modern Human Infants with Carbon and Nitrogen Stable Isotope Ratios. American Journal of Physical Anthropology 129:279-293.

Fuller, Benjamin T., Theya Molleson, David A. Harris, Laren T. Gilmour, and Robert E. M. Hedges

2006 Isotopic Evidence for Breastfeeding and Possible Adult Dietary Differences from Late-Sub-Roman Britain. American Journal of Physical Anthropology 129:45-54

Fuller, Benjamin T., Michael P. Richard, and S. A. Mays

2003 Stable Carbon and Nitrogen Isotope Variations in Tooth Dentine Serial Sections from Wharram Percy. Journal of Archaeological Science 30:16731684

Greenwald, Alexandra M., Jelmer W. Eerkens, and Eric J. Bartelink

2016 Stable Isotope Evidence of Juvenile Foraging in Prehistoric Central California. Journal of Archaeological Science: Reports 7:146-154.

Gruspier, Katherine L.

1999 Subadult Growth and Health from Ossuary Samples of Prehistoric Southern Ontario Iroquoian Populations. Unpublished Ph.D. dissertation, Department of Anthropology, University of Toronto, Toronto, Ontario, Canada.

Hadley, Craig, Fasil Tessama, and Ayalew T. Muluneh

2012 Household Food Insecurity and Caregiver Distress: Equal Threats to Child Nutritional Status? American Journal of Human Biology 24:149-157. 
Hart, John P., and William A. Lovis

2013 Reevaluating What We Know about the Histories of Maize in Northeastern North America: A Review of Current Evidence. Journal of Archaeological Research 21:175-216.

Health Canada

2016 Nutrition and Healthy Eating: Infant Feeding. Electronic document, http://www.hc-sc.gc.ca/ fn-an/nutrition/infant-nourisson/index-eng.php, accessed June 24, 2016

Heidenreich, Conrad E.

1971 Huronia: A History and Geography of the Huron Indians, 1600-1650. McClelland and Stewart Ltd. Toronto.

Hillson, Simon

1996 Dental Anthropology. Cambridge University Press, Cambridge.

2014 Tooth Development in Human Evolution and Bioarchaeology. Cambridge University Press, Cambridge.

Humphrey, Louise

2010 Weaning Behavior in Human Evolution. Seminars in Cell and Developmental Biology 21:453-461.

2014 Isotopic and Trace Element Evidence of Dietary Transitions in Early Life. Annals of Human Biology 41:348-357.

Jerkić, Sonja M.

1969 The Maurice Ossuary (BeHa-1). In Palaeoecology and Ontario Prehistory, edited by William M. Hurley and Conrad E. Heidenreich. Research Report 1, pp. 4961. Department of Anthropology, University of Toronto, Toronto, Ontario, Canada.

1975 An Analysis of Huron Skeletal Biology and Mortuary Practices: The Maurice Ossuary. Unpublished Ph.D. dissertation, Department of Anthropology, University of Toronto.

Kapches, Mima

1976 The Interment of Infants of the Ontario Iroquois. Ontario Archaeology 27:29-39.

Kaplan, Hillard, Kim Hill, Jane Lancaster, and Magdalena A. Hurtado

2000 A Theory of Human Life History Evolution: Diet, Intelligence, and Longevity. Evolutionary Anthropology 9(4):156-185.

Katzenberg, M. Anne, D. Ann Herring, and Shelley R. Saunders

1996 Weaning and Infant Mortality: Evaluating the Skeletal Evidence. Yearbook of Physical Anthropology 39:177-199.

Katzenberg, M. Anne, and Susan Pfeiffer

1995 Nitrogen Isotope Evidence for Weaning Age in a Nineteenth-Century Canadian Skeletal Sample. In Bodies of Evidence: Reconstructing History Through Skeletal Analysis, edited by Anne, L. Grauer, pp. 221236. Wiley-Liss, New York.

McDade, Thomas W.

2001 Parent-Offspring Conflict and the Cultural Ecology of Breast-Feeding. Human Nature 12:9-25.

McNeilly, Alan S.

1994 Physiological Mechanisms Underlying Lactational Amenorrhea. Annals of the New York Academy of Sciences 18(709):145-155.

Merrett, Deborah C.

2003 Moatfield Demography. In Bones of the Ancestors: The Archaeology and Osteobiography of the Moatfield Ossuary, edited by Ronald, F. Williamson and Susan Pfeiffer, pp. 171-188. Archaeological Paper
No. 163. Canadian Museum of Civilization, Gatineau, Canada.

Motykova, Karla

1969 Seventeenth-Century Huron Glass Beads. In Palaeoecology and Ontario Prehistory, edited by William M. Hurley and Conrad, E. Heidenreich, Research Report No. 1, pp. 88-104. Department of Anthropology, University of Toronto, Toronto, Ontario, Canada.

Mullen, Grant

1990 Human Osteology of the Warminster Site (BdGv-1) Ossuary. Unpublished Master's thesis, Department of Anthropology, University of Toronto.

Nanci, Antonio

2012 Ten Cate's Oral Histology: Development, Structure and Function. 8th ed. Elsevier, St. Louis, Missouri.

Pereira, Rosangela A., and Allison Hodge

2015 Food Insecurity: A Critical Public Health Nutrition Concern. Public Health Nutrition 18:28932894.

Pfeiffer, Susan

1980 Spatial Distribution of Human Skeletal Material within an Iroquoian Ossuary. Canadian Journal of Archaeology 4:169-172.

Pfeiffer, Susan, and Scott Fairgrieve

1994 Evidence from Ossuaries: The Effect of Contact on the Health of Iroquoians. In In the Wake of Contact: Biological Responses to Conquest, edited by Clark, S. Larsen and George Milner, pp. 47-61. A.R. Liss, New York.

Pfeiffer, Susan, and Louis Lesage

2014 The Repatriation of Wendat Ancestors. Canadian Journal of Archaeology 38:1-22.

Pfeiffer, Susan, Judith C. Sealy, Ronald F. Williamson, Suzanne Needs-Howarth, and Louis Lesage

2016 Maize, Fish, and Deer: Investigating Dietary Staples among Ancestral Huron-Wendat Villages, as Documented from Tooth Samples. American Antiquity 81:515-532.

Pfeiffer, Susan, Ronald F. Willamson, Judith C. Sealy, David G. Smith, and Meradeth H. Snow

2014 Stable Dietary Isotopes and mtDNA from Woodland Period Southern Ontario People: Results from a Tooth Sampling Protocol. Journal of Archaeological Science 42:334-345

Reynard, Linda M., and Noreen Tuross

2015 The Known, the Unknown and the Unknowable: Weaning Times from Archaeological Bones Using Nitrogen Isotope Ratios. Journal of Archaeological Science 53:618-625.

Richards, Michael P., Benjamin T. Fuller, and T. Molleson

2006 Stable Isotope Paleodietary Study of Humans and Fauna from the Multi-period (Iron Age, Viking and Late Medieval) Site of Newark Bay, Orkney. Journal of Archaeological Science 33:122131.

Saunders, Shelley R., and F. Jerome Melbye

1990 Subadult Mortality and Skeletal Indicators of Health in Late Woodland Ontario Iroquois. Canadian Journal of Archaeology 14:61-74.

Schurr, Mark R., and Mary L. Powell

2005 The Role of Changing Childhood Diets in the Prehistoric Evolution of Food Production: An Isotopic Assessment. American Journal of Physical Anthropology 126:278-294. 
Sealy, Judith, Malia Johnson, Michael Richards, and Olaf Nehlich

2014 Comparison of Two Methods of Extracting Bone Collagen for Stable Carbon and Nitrogen Isotope Analysis: Comparing Whole Bone Demineralization with Gelatinization and Ultrafiltration. Journal of Archaeological Science 47:64-69.

Sellen, Daniel W.

2001 Comparison of Infant Feeding Patterns Reported for Nonindustrial Populations with Current Recommendations. Journal of Nutrition 131:2707-2715.

2009 Evolution of Human Lactation and Complementary Feeding: Implications for Understanding Contemporary Cross-cultural Variation. In Breast-feeding: Early Influences on Later Health, edited by Gail Goldberg, Andrew Prentice, Ann Prentice, Suzanne Filteau, and Kirsten Simondon, pp. 253-282. Springer, New York.

Sellen, Daniel W., and Diana B. Smay

2001 Relationship between Subsistence and Age at Weaning in "Preindustrial" Societies. Human Nature 12:4787.

Snodgrass, J. Josh

2012 Human Energetics. In Human Biology: An Evolutionary and Biocultural Perspective, edited by Sara Stinson, Barry Bogin, and Dennis O'Rourke, pp. 325-384. John Wiley and Sons, Hoboken, New Jersey.

Stuiver, Minze, and Paula J. Reimer

1993 Extended ${ }^{14} \mathrm{C}$ Data Base and Revised CALIB 3.0 14C Age Calibration Program, Radiocarbon 35:215230.

Sykes, Clark

1983 An Archaeological and Ethnohistorical Analysis of Huron Intra-community Exchange Systems. Unpublished Ph.D. dissertation, Department of Anthropology, University of Toronto, Toronto, Ontario, Canada.

Thwaites, Reuben Gold

1896-1901 The Jesuit Relations and Allied Documents. 73 vols. Burrows Brothers Company, Cleveland, Ohio.

Tooker, Elizabeth

1964 An Ethnography of the Huron Indians, 1615 1649. Bulletin No. 190, Bureau of American Ethnology, Smithsonian Institution, Washington, D.C.

Trigger, Bruce G.

1969 The Huron Farmers of the North. Holt, Rinehart and Winston, New York.

1976 The Children of Aataentsic: A History of the Huron People to 1660. 2 vols. McGill-Queen's University Press, Montreal.

Tsutaya, Takumi, and Minoru Yoneda

2015 Reconstruction of Breastfeeding and Weaning Practices Using Stable Isotope and Trace Element Analysis: A Review. Yearbook of Physical Anthropology 156(S59):2-21.

van der Merwe, Nikolaas J., Ronald F. Williamson, Susan Pfeiffer, Stephen C. Thomas, and Kim O. Allegretto

2003 The Moatfield Ossuary: Isotopic Dietary Analysis of an Iroquoian Community, Using Dental Tissue. Journal of Anthropological Archaeology 22:245-261.
Warinner, Christina, Nelly Robles Garcia, and Noreen Tuross 2013 Maize, Beans and the Floral Isotopic Diversity of Highland Oaxaca, Mexico. Journal of Archaeological Science 40:868-873.

Warrick, Gary A.

2008 A Population History of the Huron-Petun, A.D. 500 1650. Cambridge University Press, Cambridge.

Wells, Jonathan C., and Jay T. Stock

2007 The Biology of the Colonizing Ape. American Journal of Physical Anthropology 134(S45):191222.

WHO

2016 Nutrition Topics: Complementary Feeding. Electronic document, http://www.who.int/nutrition/topics/ complementary_feeding/en/, accessed June 24, 2016.

Williamson, Ronald $\bar{F}$.

2014 The Archaeological History of the Wendat to A.D. 1651: An Overview. Ontario Archaeology 94:364.

Williamson, Ronald F., and Susan Pfeiffer (editors)

2003 Bones of the Ancestors: The Archaeology and Osteobiography of the Moatfield Site. Archaeological Survey of Canada, Mercury Series Paper No. 163. Canadian Museum of Civilization, Hull, Quebec.

Williamson, Ronald F., and D. A. Steiss

2003 A History of Iroquoian Multiple Burial Practice. In Bones of the Ancestors: The Archaeology and Osteobiography of the Moatfield Ossuary, edited by Ronald F. Williamson and Susan Pfeiffer, pp. 89132. Archaeological Survey of Canada, Mercury Series Paper No. 163. Canadian Museum of Civilization, Hull, Quebec.

Wright, Lori E., and Henry P. Schwarcz

1999 Correspondence between Stable Carbon, Oxygen and Nitrogen Isotopes in Human Tooth Enamel and Dentine: Infant Diets at Kaminaljuyu. Journal of Archaeological Science 26:1159-1170.

Wrong, George M. (editor)

1939 The Long Journey to the Country of the Hurons, by Gabriel Sagard (1632). Champlain Society, Toronto.

\section{Note}

1. There is some disparity in values for the completion of the $M_{1}$ crown. Citing diverse sources, Hillson (1996) identifies a range of 2.0 to 3.2 years of age. Median values in the London Atlas show the crown three-fourths complete at age 2.5 , and the root initiated at age 3.5. Hence, in that reference, crown completion is much closer to age 3 than to age 2 years.

Submitted July 15, 2016; Revised September 13, 2016;

Revised October 16, 2016; Accepted October 18, 2016 